University of Nebraska - Lincoln

DigitalCommons@University of Nebraska - Lincoln

Occurrence of Cyanazine Compounds in Groundwater: Degradates More Prevalent Than the Parent Compound

\author{
Dana Kolpin \\ U.S. Geological Survey \\ E. Michael Thurman \\ U.S. Geological Survey \\ S. Michael Linhart \\ U.S. Geological Survey
}

Follow this and additional works at: https://digitalcommons.unl.edu/usgsstaffpub

Part of the Earth Sciences Commons

Kolpin, Dana; Thurman, E. Michael; and Linhart, S. Michael, "Occurrence of Cyanazine Compounds in Groundwater: Degradates More Prevalent Than the Parent Compound" (2001). USGS Staff -- Published Research. 69.

https://digitalcommons.unl.edu/usgsstaffpub/69

This Article is brought to you for free and open access by the US Geological Survey at DigitalCommons@University of Nebraska - Lincoln. It has been accepted for inclusion in USGS Staff -- Published Research by an authorized administrator of DigitalCommons@University of Nebraska - Lincoln. 


\section{Occurrence of Cyanazine Compounds in Groundwater: Degradates More Prevalent Than the Parent Compound}

\author{
DANA W. KOLPIN,*, \\ E. MICHAEL THURMAN, $\neq A N D$ \\ S. MICHAEL LINHART' ${ }^{\dagger}$
}

U.S. Geological Survey, 400 South Clinton Street,

P.O. Box 1230, lowa City, lowa 52244, and U.S. Geological Survey, 4821 Quail Crest Place, Lawrence, Kansas 66049

A recently developed analytical method using liquid chromatography/mass spectrometry was used to investigate the occurrence of cyanazine and its degradates cyanazine acid (CAC), cyanazine amide (CAM), deethylcyanazine (DEC), and deethylcyanazine acid (DCAC) in groundwater. This research represents some of the earliest data on the occurrence of cyanazine degradates in groundwater. Although cyanazine was infrequently detected in the 64 wells across lowa sampled in 1999, cyanazine degradates were commonly found during this study. The most frequently detected cyanazine compound was DCAC (32.8\%) followed by CAC $(29.7 \%)$, CAM $(17.2 \%)$, DEC $(3.1 \%)$, and cyanazine (3.1\%). The frequency of detection for cyanazine or one or more of its degradates (CYTOT) was more than 12-fold over that of cyanazine alone $339.1 \%$ for CYTOT versus $3.1 \%$ for cyanazine). Of the total measured concentration of cyanazine, only $0.2 \%$ was derived from its parent compoundwith DCAC (74.1\%) and CAC (18.4\%) comprising $92.5 \%$ of this total. Thus, although DCAC and CAC had similar frequencies of detection, DCAC was generally present in higher concentrations. No concentrations of cyanazine compounds for this study exceeded water-quality criteria for the protection of human health. Only cyanazine, however, has such a criteria established. Nevertheless, because these cyanazine degradates are still chlorinated, they may have similar toxicity as their parent compoundsimilar to what has been found with the chlorinated degradates of atrazine. Thus, the results of this study documented that data on the degradates for cyanazine are critical for understanding its fate and transport in the hydrologic system. Furthermore, the prevalence of the chlorinated degradates of cyanazine found in groundwater suggests that to accurately determine the overall effect on human health and the environment from cyanazine its degradates should also be considered. In addition, because CYTOT was found in $57.6 \%$ of the samples collected from alluvial aquifers, about $2-5$ times more frequently than the other major aquifer types (glacial drift, bedrock/karst, bedrock/ nonkarst) under investigation, this finding has long-term implications for the occurrence of CYTOT in streams. It is anticipated that low-level concentrations of CYTOT will continue to be detected in streams for years after the use of cyanazine has terminated (scheduled for the year
2000 in the United States), primarily through its movement from groundw ater into streams during base-flow conditions.

\section{Introduction}

Complete mineralization of most parent herbicide compounds occurs slowly in the environment (1). However, relatively stable and persistent degradates can be formed during the transformation of many herbicides (2). Indeed, research has shown that herbicide degradates are prevalent in groundwater-often being more frequently detected than their parent compounds (3-5). These degradates can either be less toxic $(6,7)$ or have similar or greater toxicity $(8,9)$ than their parent compounds. Thus, it becomes imperative that information on major degradation pathways for heavily used herbicides are identified, analytical methods are developed to determine environmental concentrations, and research is conducted to determine effects to human health and the environment.

Cyanazine has historically been one of the most heavily used herbicides in the country, with roughly 9 million $\mathrm{kg}$ being used annually in theU nited States (10). Cyanazine use in the United States, however, is scheduled to end in theyear 2000 (http:// www.epa.gov/ pesticides/ citizens/ triazine.htm). The degradation pathway for cyanazine is shown in Figure 1. The effect of these degradates on human health, however, are generally unknown. Because these cyanazine degradates are still chlorinated (Figure 1), it is anticipated that these degradates could be similar to the chlorinated degradates for atrazine (deethylatrazine and deisoproplyatrazine) that have been found to be phytotoxic $(11,12)$. Indeed, cyanazine amide (CAM) has been shown to retain some of the herbicidal activity of the parent compound (13).

Research has suggested that because of the persistence of the s-triazine ring that degradates of cyanazine will be found in groundwater once they are looked for (14). Indeed, research has documented the presence of CAM and DIA in groundwater $(3,4)$. Little data have been obtained on the environmental occurrence of other cyanazine degradates due to the inherent difficulty in measuring these compounds (15). Recently, however, a sensitive and reliable method has been developed to measure cyanazine and its major degradates using liquid chromatography/ mass spectrometry (LC/MS) $(16,17)$.

This paper describes the results of a study to determine the occurrence of cyanazine and its degradates (CAC, CAM, deethylcyanazine(DEC), and deethylcyanazineacid (DCAC)), in groundwater. Results from the sampling of 64 municipal wells across lowa during the summer of 1999 are presented (Figure 2). To our knowledge, this is the first large-scale investigation for CAC, DEC, and DCAC in water resources and is one of the most detailed studies on the occurrence of cyanazine compoundsin ground water to date. This research is an extension of the multi-agency lowa Ground Water Monitoring (IGWM) Program (18, 19).

\section{Methods}

In 1992, a network of 90 sampling sites were randomly selected from an inventory of over 2000 lowa municipal wells representing all major aquifer types (alluvial, glacial drift,

* Corresponding author e-mail: dwkolpin@usgs.gov; phone: (319)358-3614; fax: (319)358-3606.

† U.S. Geological Survey, Iowa City, IA

‡ U.S. Geological Survey, Lawrence, KS.

VOL. 35, NO. 6, 2001 / ENVIRONMENTAL SCIENCE \& TECHNOLOGY • 1217 


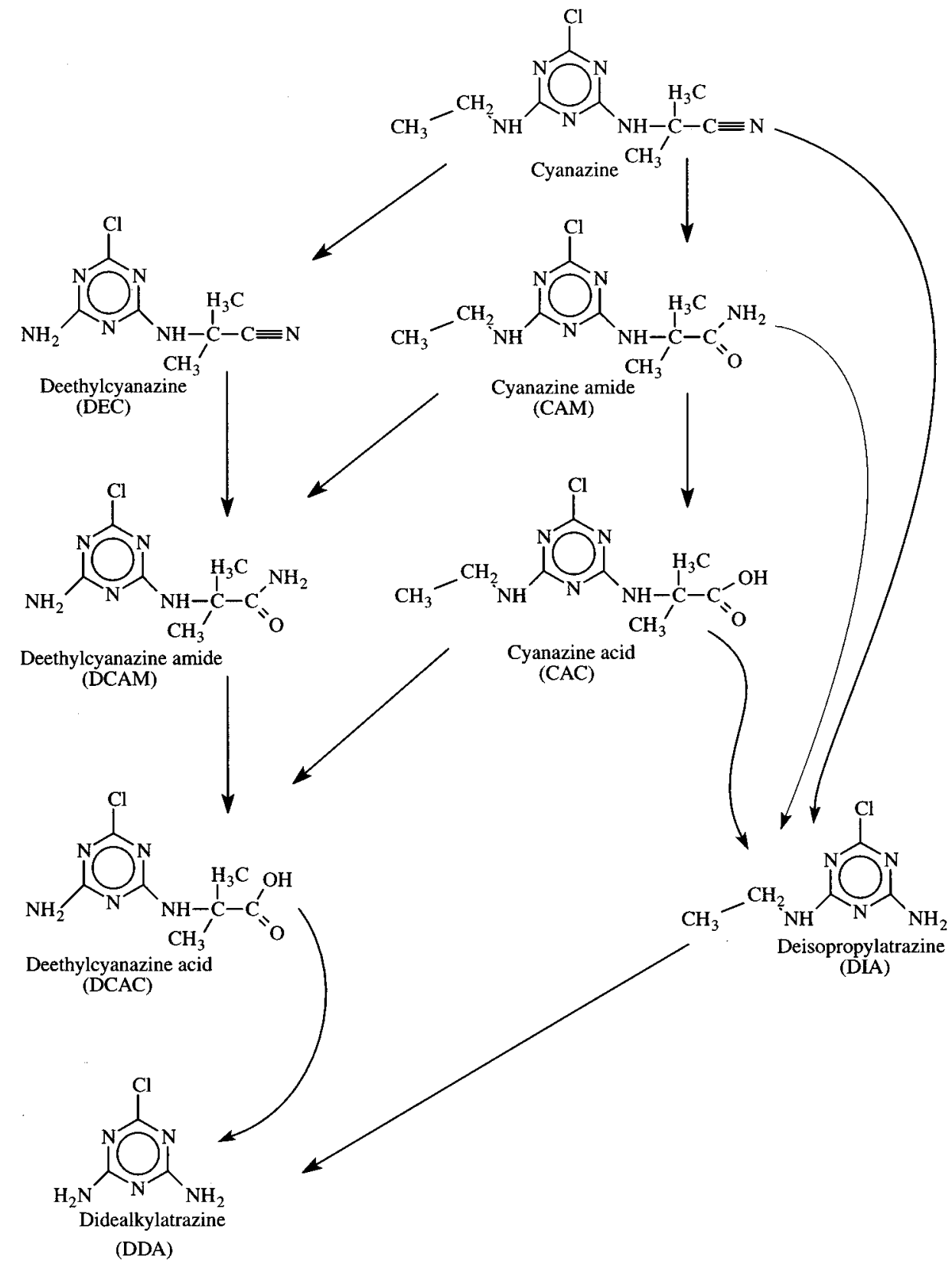

FIGURE 1. Pathways for degradation of cyanazine (17).

bedrock/karst region, and bedrock/nonkarst region). The number of selected sampling sites from the major aquifer types was designed to represent the distribution of all municipal wells in Iowa. The annual sampling schedule, however, was such that wells suspected to be minimally impacted by land-applied chemicals were sampled less frequently (every $2-4 \mathrm{yr}$ rather than annually). The water samples collected from the 64 wells (Figure 2) represent the sampling carried out for the IGWM during 1999. Wellsthought to be least susceptible to land-applied chemicals were not sampled during this time period.

The sampling protocol for this study has been reported previously (20). All wells were pumped for at least $30 \mathrm{~min}$ before dissolved oxygen, $\mathrm{pH}$, specific conductance, and water temperature were measured. Once the values for these parameters stabilized, the water samples were collected.

Water samples were filtered through a $0.7-\mu \mathrm{m}$ glass fiber filter into $125-\mathrm{mL}$ amber baked-glass bottles, immediately chilled, and sent by overnight air express to the U.S.
Geological Survey Organic Research Laboratory in Lawrence, $\mathrm{KS}$. Concentrations of cyanazine and its degradates CAC, CAM, DEC, and DCAC were analyzed from the $125-\mathrm{mL}$ ground water samplesusing a newly developed method using LC/MS. Details of this method havebeen described previously $(16,17)$. The analytical reporting limit for this method was $0.01 \mu \mathrm{g} / \mathrm{L}$.

Total cyanazine residue (CYTOT) was determined by summation of cyanazine, CAC, CAM, DEC, and DCAC concentrations. Measured concentrations that wereless than the analytical reporting limit for any of the individual concentrations were treated as zero in the calculation of CYTOT. Because deisopropylatrazine can also be derived from the degradation of atrazine (17), it was not included in the calculation of CYTOT.

TheKruskal-Wallistest (21) is a nonparametric statistical method that was used to test for differences among groups of data. Test results were evaluated at the 0.05 level of significance. 


\section{Explanation}

- Alluvial aquifer well location

- Glacial-drift aquifer well location

$\nabla$ Bedrock/karst region well location

$\Delta \quad$ Bedrock/nonkarst region well location

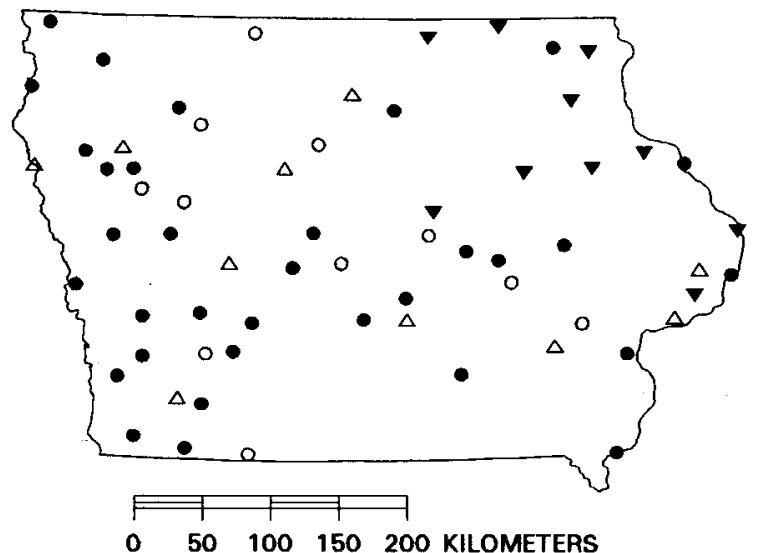

FIGURE 2. Location of municipal wells sampled in low a during 1999.

\section{Results}

Similar to previous pesticideinvestigations $(4,22)$, cyanazine was infrequently detected in groundwater for this study (Figure 3). Several of the cyanazine degradates, however, were much more frequently detected in groundwater than its parent compound (Figure3). The more frequent presence of CAC and CAM over cyanazine is in agreement with the reported greater stability of these degradates after transformation from cyanazine $(13,15,16)$. The cyanazine compounds with the greatest frequency of detection (CAC and DCAC) are organic acids and as such are negatively charged at the $\mathrm{pH}$ of groundwater. Thus, these negatively charged species are soluble and more likely to be transported to groundwater than cyanazine. These results are similar to that for alachlor and metolachlor, which each form an oxanilic acid (17) that is transported to groundwater much more readily than their parent compounds (4). The detection of total cyanazine residue (CYTOT) increased more than 12fold over that of just the parent compound, with maximum concentrations of CYTOT $(3.3 \mu \mathrm{g} / \mathrm{L}) 165$ times that for cyanazine $(0.02 \mu \mathrm{g} / \mathrm{L})$ (Figure 3$)$.

Of the total measured concentration of cyanazine, only $0.2 \%$ was from its parent compound (Figure 4). For comparison, parent compounds also comprised a minority of the total measured concentrations for acetochlor $(0 \%)$, alachlor (0\%), atrazine (40.0\%), and metolachlor (6.9\%) during this investigation. Two cyanazine degradates (DCAC and CAC) comprised $92.5 \%$ of the measured cyanazine concentrations for this study (Figure 4). Although DCAC and CAC have similar frequencies of detection (Figure 3), DCAC was generally present in higher concentrations. Conversely, it appears that cyanazine and DEC are relatively unstable with little transport to groundwater (Figures 3 and 4). As hypothesized previously $(15,23)$, cyanazine may degrade through various pathways to deisopropylatrazine and dideakylatrazine(Figure 1), compounds that arealso derived from the degradation of atrazine.

No concentrations of cyanazine compounds for this study exceeded water-quality criteria for the protection of human health. Only cyanazine however has such a criteria established-having an unenforceable health advisory level

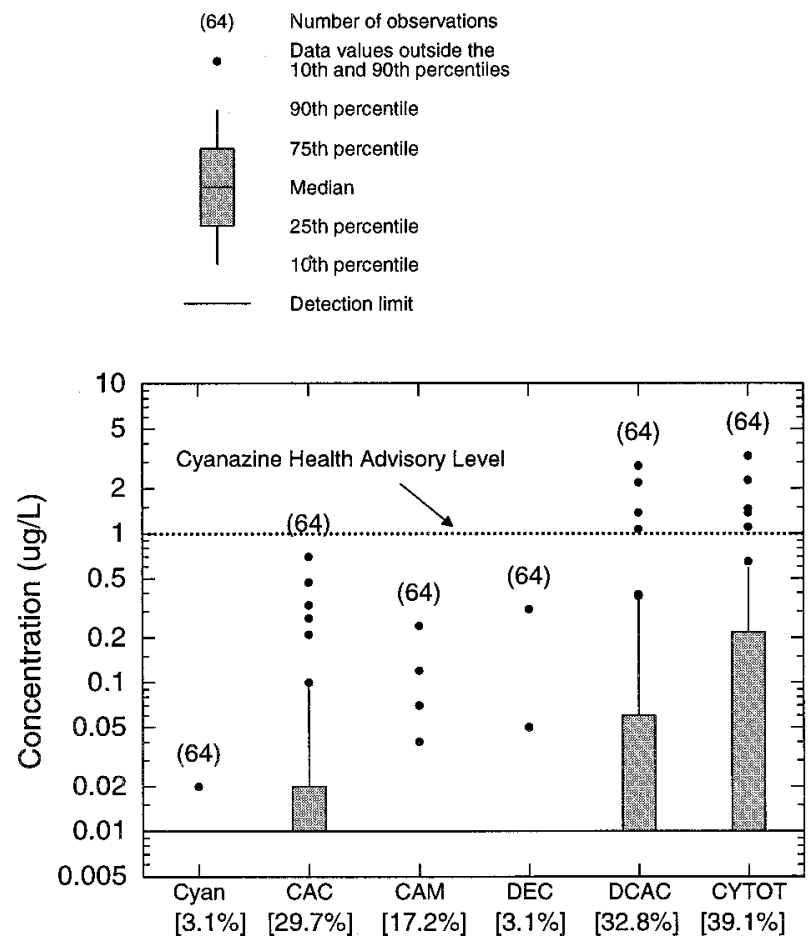

FIGURE 3. Concentration of cyanazine; its degradates cyanazine acid (CAC), cyanazine amide (CAM), deethylcyanazine (DEC), and deethylcyanazine acid (DCAC); and the summation of cyanazine + CAC + CAM + DEC + DCAC (CYTOT) in groundwater samples collected in low a 1999. Numbers in brackets are the frequencies of detection.

EXPLANATION

MIIII DCAC

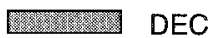

EIIID CAM

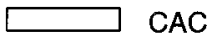

Cyanazine

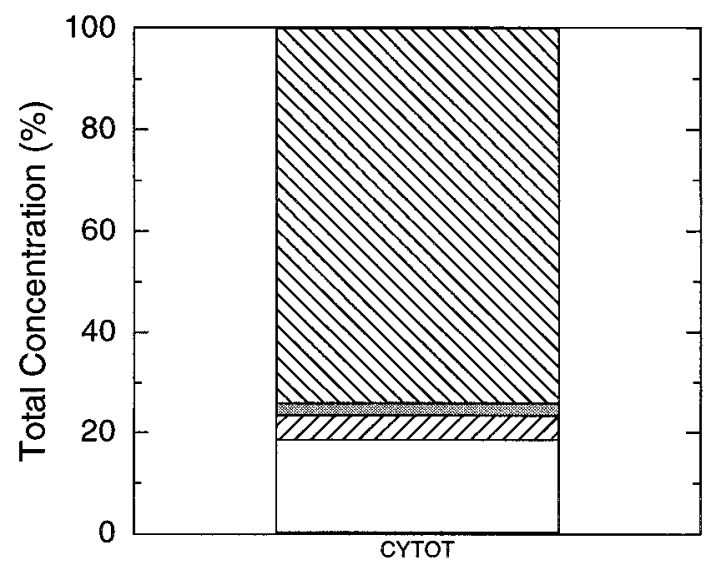

FIGURE 4. Percent of total measured concentration derived from the cyanazine compounds under investigation.

set at $1.0 \mu \mathrm{g} / \mathrm{L}$. Making the gross assumption that the chlorinated degradates may havesimilar toxicity as the parent compound-similar to what has been found with the 
Explanation

Cyanazine detected

- Cyanazine degradates detected

$\times \quad$ Cyanazine and cyanazine degradates analyzed but not detected

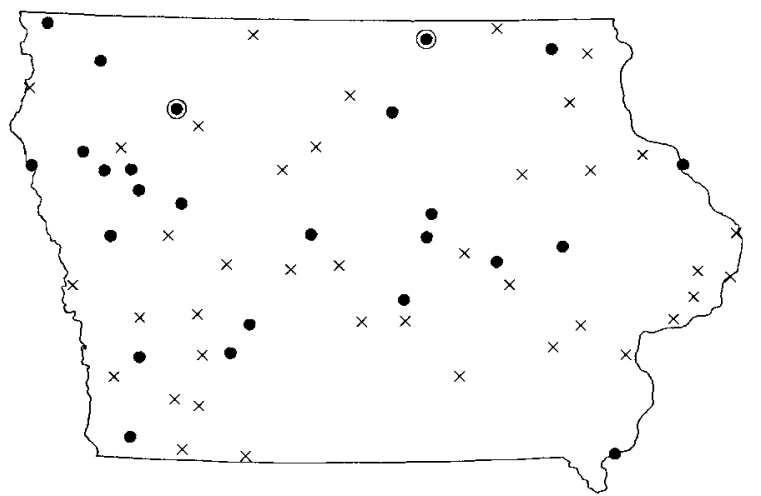

FIGURE 5. Spatial occurrence of cyanazine and CYTOT (summation of cyanazine and its degradates) in the groundwater samples collected in low a 1999.

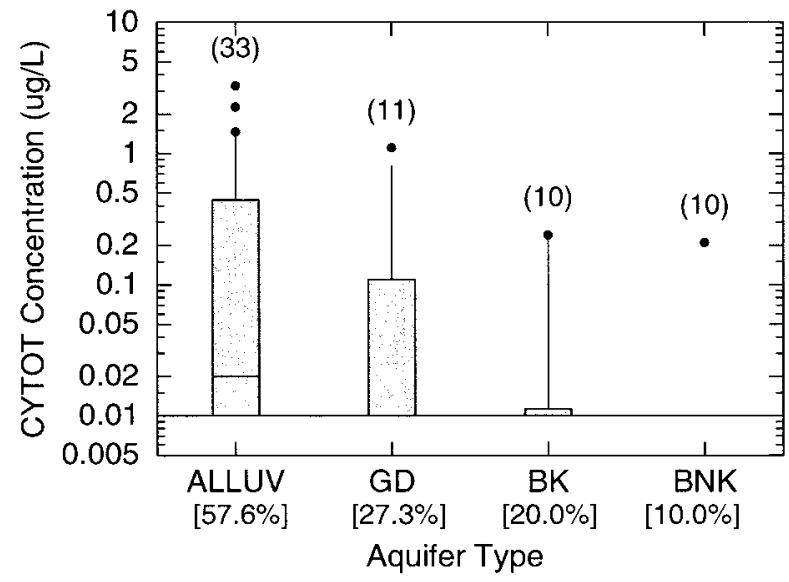

FIGURE 6. CYTOT (summation of cyanazine and its degradates) concentration by aquifer type for the samples collected in low a 1999 (ALLUV = alluvial, GD = glacial drift, BK = bedrock/karst region, and $B N K=$ bedrock/nonkarst region). Numbers in brackets are the frequency of CYTOT detection for each group. An explanation of a boxplot is provided in Figure 3.

chlorinated degradates of atrazine (24)-then $7.8 \%$ of the CYTOT concentrations exceeded the health advisory level for cyanazine.

The results of this study documented that data on the degradates for cyanazine are critical for understanding its fate and transport in the hydrologic system, similar to what has been found with acetochlor, alachlor, atrazine, and metolachlor $(3,4,25,26)$. Furthermore, the prevalence of the chlorinated degradates of cyanazine found in groundwater suggests that to accurately determine the overall effect of cyanazine on human health and the environment its degradates should also be considered.

Although there is no apparent geographical pattern to the presence of CYTOT in groundwater (Figure 5), the data did vary hydrogeologically. A significant difference $(p=0.014$, Kruskal-Wallis test) in the occurrence and concentration of CYTOT was determined among the major aquifer types sampled (Figure 6). The occurrence of CYTOT was much more prevalent in alluvial aquifers, being found about 2-5 times more frequently than the other major aquifer types sampled. In contrast, cyanazine occurrence rates did not significantly differ ( $p=0.517$, Kruskal-Wallis test) among the major aquifer types sampled.

The relative infrequency with which CYTOT was detected in the bedrock/ karst aquifers (Figure 6) is in sharp contrast to that determined from an earlier study of herbicides and herbicide degradates where $77.4 \%$ of the bedrock/karst aquifers were found to have these compounds present (4). Most of these herbicide detections were from select degradates of alachlor and metolachlor (4). The lower frequency of detection found for CYTOT as compared to the earlier study of herbicide degradates in groundwater might be an artifact of the smaller number of bedrock/ karst wellssampled in 1999.

Because of the strong interaction between groundwater and surface water within alluvial systems (27), the prevalence of CYTOT in alluvial aquifers has potential long-term implications for the occurrence of CYTOT in streams. Cyanazine compounds can betransported to alluvial aquifers through a variety of processes such as infiltration through the unsaturated zone following application to soils being farmed in the flood plain $(28,29)$, episodic stream flooding (30), bank storage of streamwater (31), and contaminated streams losing water to the groundwater system (32). Many streams across the Midwest receive significant groundwater contributions to streamflow-particularly during base-flow conditions. Therefore, once an alluvial aquifer becomes contamination with cyanazine compounds, it can provide a long-term source of CYTOT to the corresponding streams. Thus, even though the use of cyanazine is nearing its end in the United States, the legacy of that use, as reflected in the presence of CYTOT in groundwater, may persist for many years because of the lag-time between changes in chemical use at the land surface and concentrations in groundwater. Consequently, it is anticipated that low-level concentrations of CYTOT will continue to befound in streams for years after the use of cyanazine has stopped-primarily through its movement from ground water into streams during base-flow conditions. Groundwater has been previously documented to be a source of herbicide concentrations to streams (33) and has been shown that its contributions to stream contamination of herbicide compounds can belong-term in nature. For example, a degradate of alachlor was one of the most frequently detected herbicide compounds in alluvial aquifers across I owa (4) even though alachlor had little use documented during the year of sample collection. Alachlor has progressively decreased from being the second most heavily used pesticide in 1990, to the 12th in 1996, to essentiallyzero use in 1999(34). Few detections of the parent compound for alachlor were found during this study. In addition, a regional study of 70 streams across the Illinois, lowa, and Minnesota during base-flow conditions in 1997 found the same alachlor degradate as one of the most frequently detected compounds (35). No detections of the parent compound for alachlor werefound during thisstream sampling. The evidence of prevalent detections of the same alachlor compounds in both alluvial aquifers and streams during base-flow conditions combined with there being multiple years since the extensive use of alachlor supports the hypothesis that alluvial aquifers can act as a long-term source of herbicide compounds to streams.

Because the wells in thisstudy were derived from a variety of aquifers and hydrogeologic settings across Iowa, groundwater age varies significantly among these wells. Previous research hasshown that the frequency of herbicide detection generally increases with decreasing water age $(36,37)$. Although no direct measures of groundwater age were obtained for this study, two indirect estimates of age were available-dissolved-oxygen concentrations and well depth 

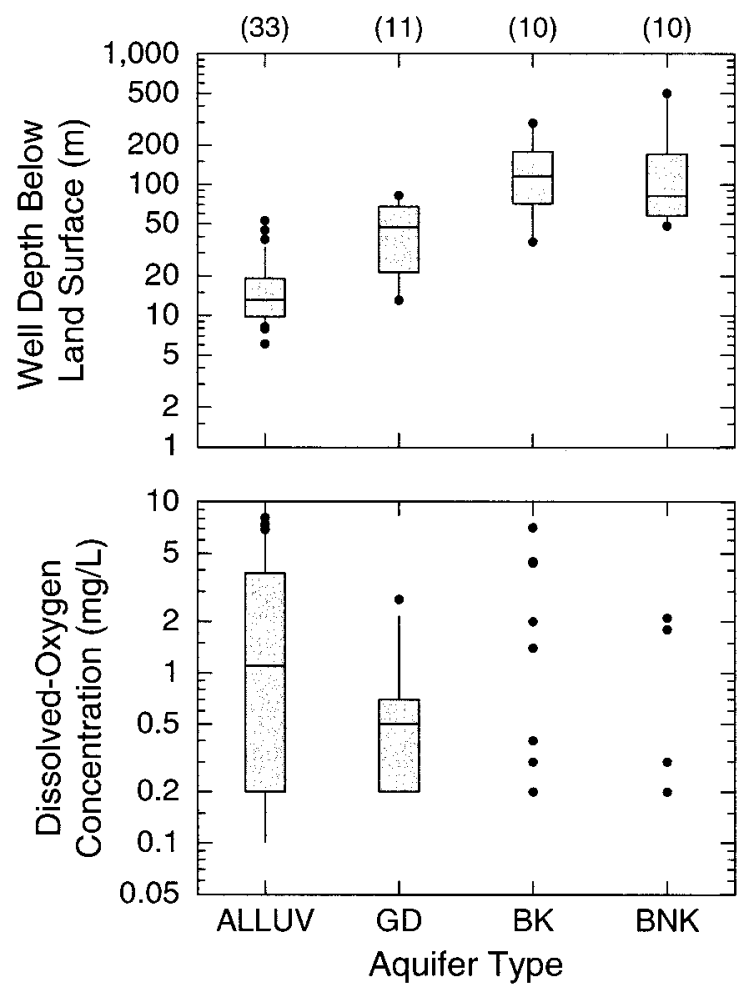

FIGURE 7. Summation by aquifer type of well depth for the sites sampled and dissolved-oxygen concentration for the corresponding w ater samples collected (ALLUV = alluvial, GD = glacial drift, BK $=$ bedrock/karst region, and BNK = bedrock/nonkarst region). An explanation of a boxplot is provided in Figure 3.

(Figure 7). Thesetwo factors can be used as general indicators of water age because oxygen is consumed through biotic and abiotic processes as water travels from zones of recharge to greater depths, and well depth providesa general indication of distance from a recharge zone (20). As done in a previous study (4), the two indirect estimates of groundwater age were used to separate the sampled wells into three general vulnerability classes:

(i) low-well depth greater than $50 \mathrm{~m}$ and dissolved-oxygen concentration less than $0.5 \mathrm{mg} / \mathrm{L}$;

(ii) intermediate-well depth greater than $50 \mathrm{~m}$ and dissolved-oxygen concentration less than or equal to $0.5 \mathrm{mg} /$ $\mathrm{L}$, or well depth greater than or equal to $50 \mathrm{~m}$ and dissolvedoxygen concentration less than $0.5 \mathrm{mg} / \mathrm{L}$;

(iii) high-well depth less than or equal to $50 \mathrm{~m}$ and dissolved-oxygen concentration greater than or equal to 0.5 $\mathrm{mg} / \mathrm{L}$.

These vulnerability classes provide a general indication of groundwater age, with low vulnerability representing the wells generally having the oldest groundwater and high vulnerability representing the wells generally having the youngest groundwater. Previous research has shown herbicide contamination to increase substantially in groundwater from the lowest to the highest vulnerability class (4).

The frequency of detection and concentration for cyanazine was not significantly different $(p=0.782$, KruskalWallis test) among the three vulnerability classes defined for this study. However, the frequency of detection and concentration did vary significantly $(p=0.001$, Kruskal-Wallis test) among the vulnerability classes when the cyanazine degradates are accounted for (Figure 8). The occurrence of CYTOT was detected about 3-4 times more frequently in the high vulnerability class (wells estimated to contain the youngest ground water) than samplesfrom theintermediateand low-vulnerability classes. Because the lag time between

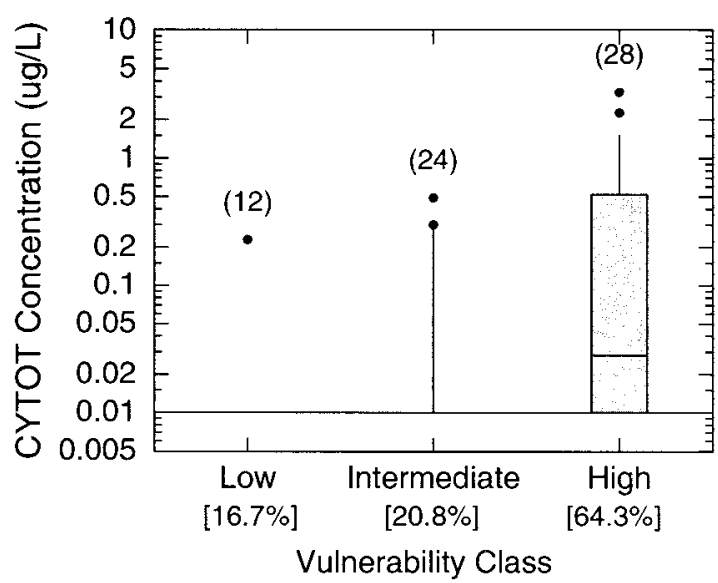

FIGURE 8. CYTOT (summation of cyanazine and its degradates) concentration by vulnerability class for the samples collected in low a 1999. Numbers in brackets are the frequency of CYTOT detection for each group. An explanation of a boxplot is provided in Figure 3.

changes in chemical use at the land surface and concentrationsin groundwater should become shorter as groundwater age decreases, it is anticipated that CYTOT concentrations will first decrease in the wells within the high vulnerability class following the termination of cyanazine use.

\section{Acknowledgments}

We thank the U.S. Environmental Protection Agency, Office of Pesticide Programs, for their funding of the laboratory analysis of groundwater for this study and the University of Iowa Hygienic Laboratory and the lowa Department of Natural Resources, Geological Survey Bureau, for their support of the IGWM.

\section{Literature Cited}

(1) Stamper, D. M.; Traina, S. J.; Tuovinen, O. H. J. Environ. Qual. 1997, 26, 488-494.

(2) Coats, J. R. CHEMTECH 1993, March, 25-29.

(3) Kolpin, D. W.; Thurman, E. M.; Goolsby, D. A. Environ. Sci. Technol. 1996, 30, 335-340.

(4) Kolpin, D. W.; Thurman, E. M.; Linhart, S. M. Sci. Total Environ. 2000, 248, 115-122.

(5) Potter, T. L.; Carpenter, T. L. Environ. Sci. Technol. 1995, 29, 1557-1563.

(6) Heydens, W. F.; Wilson, A. G. E.; Kraus, L. J.; Hopkins, W. E.; Hotz, K. J. Toxicol. Sci. 2000, 55, 36-43.

(7) Stamper, D. M.; Tuovinen, O. H. Crit. Rev. Microbiol. 1998, 24 $1-22$.

(8) Belfoid, A. C.; van Drunen, M.; Beek, M. A.; Schrap, S. M.; van Gestel, C. A. M.; van Hattum, B. Sci. Total Environ. 1998, 22, 167-183.

(9) Tessier, D. M.; Clark, J. M. J. Agric. Food Chem. 1995, 43, 2504 2512.

(10) Aspelin, A. L.; Grube, A. H. U.S. EPA No. 733-R-99-001; U.S. Government Printing Office, Washington, DC, 1999.

(11) Kaufman, D. D.; Kearney, P. C. ResidueRev. 1970, 32, 235-265.

(12) Panshin, S. Y.; Carter, D. S.; Bayless, E. R. Environ. Sci. Technol. 2000, 34, 2131-2137.

(13) Reddy, K. N.; Locke, M. A.; Zablotowicz, R. M. Weed Sci. 1997, 45, 727-732

(14) Barrett, M. R. In Herbicide Metabolites in Surface Water and Groundwater; Meyer, M. T., Thurman, E. M., Eds.; ACS Symposium Series 630; American Chemical Society: Wahington, DC, 1995; pp 200-225.

(15) Meyer, M. T. Ph.D. Thesis, Department of Geology, University of Kansas, 1994; 364 pp.

(16) Ferrer, I.; Thurman, E. M.; Barcelo, D. Environ. Sci. Technol. 2000, 34, 714-718.

(17) Scribner, E. A.; Thurman, E. M.; Zimmerman, L. R. Sci. Total Environ. 2000, 248, 157-167.

(18) Detroy, M. G. Open-FileRep.-U.S. Geol. Surv. 1985, No. 84-815. 
(19) Kolpin, D. W.; Sneck-Fahrer, D. A.; Hallberg, G. R.; Libra, R. D. J. Environ. Qual. 1997, 26, 1007-1017.

(20) Kolpin, D. W.; Kalkhoff, S. J.; Goolsby, D. A.; Sneck-Fahrer, D. A.; Thurman, E. M. Ground Water 1997, 35, 679-688.

(21) Helsel, D. R.; Hirsch, R. M. Statistical methodsin water resources; Elsevier: New York, 1992.

(22) Kolpin, D. W.; Barbash, J. E.; Gilliom, R. J. Ground Water 2000, $38,858-863$

(23) Thurman, E. M.; Meyer, M. T.; Mills, M. S.; Zimmerman, L. R.; Perry, C. A. Environ. Sci. Technol. 1994, 28, 2267-2277.

(24) Ciba-Geigy Corporation. Summary of toxicologic data on atrazine and its chlorotriazine metabolites; Attachment 12, 56-FR3526; Ciba-Geigy: 1993.

(25) Kolpin, D. W.: Thurman, E. M.; Linhart, S. M. Arch. Environ. Contam. Toxicol. 1998, 35, 385-390.

(26) Phillips, P. J.; Wall, G. R.; Thurman, E. M.; Eckhardt, D. A.; Vanhoessen, J. Environ. Sci. Technol. 1999, 33, 3531-3537.

(27) Winter, T. C.; Harvey, J. W.; Franke, O. L.; Alley, W. M. Geol. Surv. Circ. (U.S.) 1998, No. 1139.

(28) Carter, A. D. Weed Res. 2000, 40, 113-112.

(29) Weed, D. A. J.; Kanwar, R. S.; Stoltenberg, D. E.; Pfeiffer, R. L. J. Environ. Qual. 1995, 24, 68-79.
(30) Squillace, P. J.; Caldwell, J. P.; Schulmeyer, P. M.; Harvey, C. A. U.S. Geol. Surv. Water-Supply Pap. 1996, No. 2448.

(31) Squillace, P. J. Ground Water 1996, 34, 121-134.

(32) Burkart, M. R.; Simpkins, W. W.; Helmke, M. F.; Squillace, P. J. J. Environ. Qual. 1999, 28, 69-74.

(33) Squillace, P. J.; Thurman, E. M.; Furlong, E. T. Water Resour. Res. 1993, 29, 1719-1729.

(34) U.S. Department of Agriculture. http:// usda.mannlib.cornell.edu/ reports/ nassr/ other/pcu-bb.

(35) Sorenson, S. K.; Porter, S. D.; Akers, K. K. B.; Harris, M. A.; Kalkhoff, S. J.; Lee, K. E.; Roberts, L. R.; Terrio, P. J. Open-File Rep.-U.S. Geol. Surv. 1999, No. 99-202.

(36) Kolpin, D. W.; Goolsby, D. A.; Thurman, E. M. J. Environ. Qual. 1995, 24, 1125-1132.

(37) Domagalski, J. L.; Dubrovsky, N. M. J. Hydrol. 1992, 130, 299338.

Received for review July 25, 2000. Revised manuscript received December 12, 2000. Accepted December 21, 2000. 